\title{
Recent developments in fatty acids profile determination in biological samples - a review
}

\author{
Progrese recente în determinarea acizilor graşi din probe \\ biologice - un review
}

\author{
Ioana Tiuca*, Katalin Nagy, Radu Oprean \\ University of Medicine and Pharmacy "I. Hatieganu”, Cluj-Napoca, Romania
}

\begin{abstract}
The present paper is a literature review of the recent years dealing with the most important separation techniques of fatty acids in biological samples. Our aim was to make a synthesis of the analytical methods used, to note the most used ones, but also to mention other methods that are less utilized, which can have important advantages (such as less time consuming, greener reagents, etc.). Gas-chromatographic separation methods were described and compared to liquid chromatographic separations of fatty acids in different types of biological samples. In the same time, the importance of determining fatty acids profiles in biological samples was revealed, pointing out the possible implications in diagnostics of different types of disorders or remarking different profiles compared to healthy states.
\end{abstract}

Keywords: fatty acids, gas-chromatography, liquid-chromatography, biological samples

\section{Rezumat}

Prezenta lucrare reprezintă un review al literaturii ultimilor ani în legătură cu cele mai importante tehnici de separare ale acizilor graşi din probe biologice. Scopul nostru a fost de a realiza o sinteză a metodelor utilizate, de a le nota pe cele mai utilizate, dar, in acelaşi timp, de a le puncta şi pe celelalte mai puţin utilizate, care ar putea avea importante avantaje (cum ar fi un consum mai mic de timp de analiză, utilizare de reactivi "verzi", etc.). Am descris şi comparat metodele de separare gaz-cromatografice cu separările lichid-cromatografice ale acizilor graşi pentru diferite tipuri de probe biologice. În acelaşi timp, am marcat importanţa determinării profilelor acizilor graşi în probe biologice, arătând posibile implicaţii în diagnosticul diferitelor tipuri de boli sau remarcând profile diferite la bolnavi comparativ cu voluntarii sănătoşi.

Cuvinte cheie: acizi graşi, cromatografie de gaze, cromatografie de lichide, probe biologice

Received: 23 ${ }^{\text {rd }}$ June 2015; Accepted: 13 ${ }^{\text {th }}$ September 2015; Published: $23^{\text {rd }}$ September 2015

*Corresponding author: Ioana Tiuca, University of Medicine and Pharmacy "I. Hatieganu” Cluj-Napoca, Cluj, Romania, e-mail: tiuca.daria@umfcluj.ro 


\section{Introduction}

In the era of search for health and well-being, fatty acids have gained an important role in human health, having a significant effect in the occurrence and prevention of cardiovascular diseases (1). In the same time, fatty acids profile has been reported to significantly influence or to be modified in a considerable way in neurologic or psychiatric diseases $(2,3)$, endocrine disorders (4) or in metabolic syndrome related illnesses, such as diabetes mellitus $(1,5,6)$.

Likewise, fatty acids profiles in ingested foods (1) or beverages $(7,8)$ can influence the state of health of a certain individual. It is well known that fish oil administered in infancy can reduce risks of allergies (9) and also, due to its high content of n-3 PUFA, can reduce the inflammation biomarkers in blood (10).

For these reasons, we consider that profiling fatty acids in blood or other biological samples can predict and even prevent an eventual state of health/illness that could occur, thus it is important to have easy, fast and cost effective methods to be able to determine the profile of fatty acids with short analysis times, high efficiency and selectivity.

Gas-chromatography and high-performance liquid chromatography are the main separation techniques used nowadays. In the separation of fatty acids, they can be used as complementary techniques: a gas-chromatographic separation is very efficient and uses very small volumes of substances, but it needs derivatization, while a liquid chromatographic separation does not necessarily need derivatization, but uses higher volumes of solvents and does not give such good separations, in terms of efficiency and resolution. Moreover, if it is coupled to a UV-Vis detector, fatty acids detection can cause troubles, because they hardly absorb in this spectral range.

The methods described in the literature for the separation and/or quantification of fatty acids in different samples are mostly gas-chro- matographic (1-3,5-8,11-22), among which most developed methods use a mass-spectrometer detector. However, liquid-chromatography $(4,17,23-31)$ has been presented by several authors and also, there are few articles which deal with other techniques such as capillary electrophoresis or infrared (IR) and Raman spectroscopy $(16,31,32)$.

The aim of this study was to sum up a literature synthesis of the most important separation techniques of fatty acids in bio-samples, revealing their importance in diagnosis of different disorders or noticing how their profiles can change or can be improved.

\section{Gas chromatography (GC)}

Gas chromatography is the first choice method for the detection and quantification of fatty acids in all types of samples. The high efficiency, high selectivity, relative low analysis times and low volume consumption make it a first selection method. However, the need for derivatization in case of fatty acids analysis can cause troubles in terms of overall reproducibility.

\subsection{Sample preparation - extraction of FA and derivatization}

In the majority of cases, the solvents used for the extraction of fatty acids from biological samples can be either hexane $(5,6,8,11,13,18,21,22)$ or $\mathrm{CHCl} 3 /$ methanol $(7,17,18-20)$. Before the derivatization of FA to their methyl esters (FAME), a saponification can be done, which separates FA from other lipids. For this purpose, $\mathrm{NaOH}$ or $\mathrm{KOH}$ in methanol can be used, then the solution is acidulated $(5,11,16)$. Also, a thin layer chromatographic separation of fatty acids from the other lipids extracted can be done $(1,14)$.

The transesterification to FAME is needed to increase the volatility of FA, which would be separated through the gas-chromatographic column. This esterification is usually done us- 
ing methanolic $\mathrm{HCl}$ or methanolic $\mathrm{BF} 3$. The last one, BF3, seems to be preferred to be used as a catalyst for the methyl-esterification reaction, at $100^{\circ} \mathrm{C}$, for $1 \mathrm{~h}(6,13,17-19)$. However, acid catalyzed reactions are used and $\mathrm{H} 2 \mathrm{SO} 4$ has also been considered as an option for the transesterification of FA to FAME $(5,19)$. The research group of Schmitz $(21,22)$ have used an unusual derivatization agent, which is acetyl-chloride, the derivatization being done at $20^{\circ} \mathrm{C}$, at 150 rpm, overnight. At the same time, for FA dosing, C17:0 can be added to the sample solution as an internal standard, before the derivatization process. However, any other FA with odd number of carbon atoms in the molecule can be used as an internal standard, since they are not synthesized in the human body.

After derivatization, FAME are usually extracted in hexane and the solution is concentrated or even the solvent is completely evaporated, when a solution of p-tert-butyl-phenol in hexane, as an antioxidant, can be added to the residue. Dichloromethane (DCM) has also been used for FAME extraction (16).

Main extraction, derivatization and separation procedures are listed in the Table I.

\subsection{FAME separation}

Fatty acids and their methyl-esters are highly non-polar compounds. In spite of this fact, most authors have chosen to use for their separation, stationary phases presenting medium to high polarity, such as Innowax columns (highly polar polyethylene glycol phase) or BPX-70 column (a stationary phase dedicated to FAME separation). These stationary phases present the advantage of giving a better resolution and efficacy, but they are less thermally stable. However, there are some studies which deal with the separation of fatty acids (derivatized to FAME) on stationary phases of low polarity, such as VF-5ms (5\%-phenyl-arylene-95\%-dimethylpolysiloxane phase). The advantage of using a non-polar stationary phase would be the wider range of temperature limits. With very few exceptions $(8,16,18)$, the mobile phase used for the separation of FAME is helium. Likewise, the detector usually coupled with a GC system is a mass spectrometer detector, but there are studies which are using the flame ionization detector $(1,6-8,15,16,18,20)$. The MS detector is preferred due to its high selectivity towards the analyte and due to the possibility to precisely identify the analytes in a spectral mass database (NIST, Wiley etc.). Sometimes, GCX$\mathrm{GC}$ can be used, for a better resolution of the analytes $(11,12)$.

The main separation conditions concerning the GC analysis of fatty acids in bio-samples have been presented in Table I. .

\section{Liquid chromatography (LC)}

Liquid chromatographic methods have been developed because the extraction and derivatization processes used in GC can often be long and time consuming and can affect the reproducibility of the method. At the same time, liquid chromatographic methods can be developed for preparative purposes.

\subsection{Sample preparation}

HPLC with fluorescence detection is a good method used for separation and quantification of fatty acids. It offers a high sensitivity and specificity, but it requires a phase of derivatization, which can be time-consuming and, in some cases, the use of toxic reagents, such as pyridine $(23,27)$, cannot be avoided. By using this method, FA were separated from saliva, serum samples, mice liver and different types of oils $(23,27)$. Analyzing several fluorescent labeling reagents used for the derivatization of carboxylic acids, difluoro-boraindacene (BODIPY) have shown the best fluorescent properties, and by taking functional groups in consideration, hydrazine and amine have higher reactivity and 


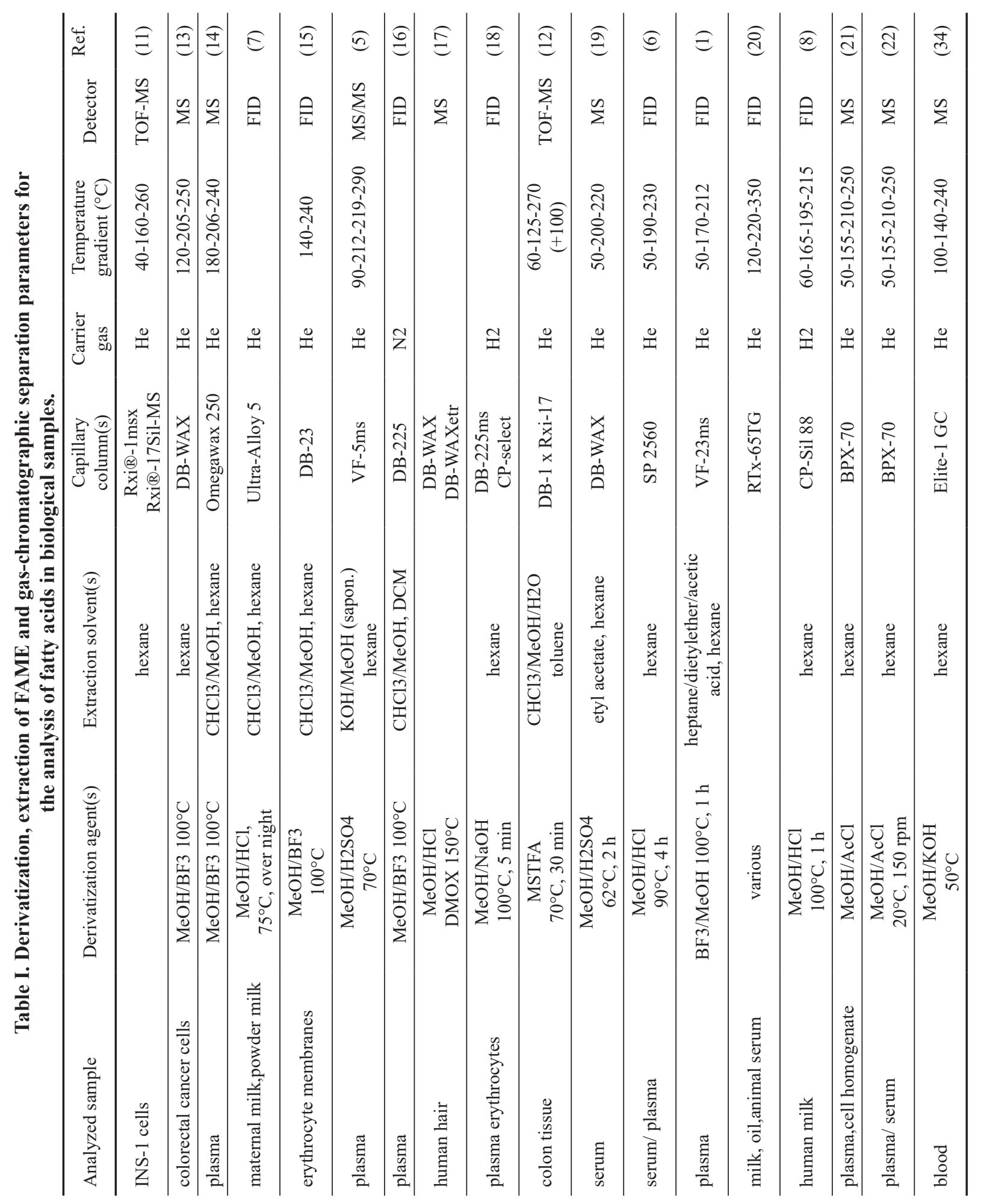


milder derivatization conditions. Combining hydrazine and BODIPY, a new derivatization reagent has been developed (27), and by using a primary aliphatic amine as the labeling group and BODIPY as the fluorophore, another, very similar derivatization agent has been developed (23). The efficiency of the derivatization is influenced by five main factors: the amount of labeling reagent, other reagents dosage, reaction time and temperature. It has been shown that the dosage of the reagent affects the efficiency of the derivatization more considerably than the other factors $(23,27)$.

Not only human serum can be analyzed by using a HPLC method, but different lipid species were separated from human meibum samples. In this case lipids were dissolved in a chloroform/ methanol mixture, and the extracts were dried by using a centrifugal concentrator (25).

Oxygenated metabolites of PUFAs (30) and fatty acid ethanolamides (FAE) (24) can also be separated by using the HPLC-MS/MS method, preceded by a solid-phase extraction. The extraction and/or a pre-concentration step is needed because the oxygenated PUFA metabolites show low physiological levels and a large number of isomers, which can harden the analytical determination (30). Because of their low concentration, the identification and separation of FAE remains problematic (24). Dasilva and co-workers compared two different cartridges, $60 \mathrm{mg}$ Oasis-HLB and $100 \mathrm{mg} \mathrm{C18}$ and also analyzed the effects of the elution solvent, sample $\mathrm{pH}$ and temperature. By using HLB cartridges better recovery results were obtained (70 to $98 \%$ ), than in the case of the $\mathrm{C} 18$ sorbent (42 to $82 \%$ ). Other studies showed that the highest extraction efficiency was obtained for ALEA, while the extraction efficiencies for AEA, DHEA and LEA were lower. Liquid-phase extraction (LPE) can be used in the case of tissue samples: liver or small intestine, but the FAE showed a less efficient extraction compared to SPE results (24).

\subsection{LC separation of $F A$}

High or ultra-performance liquid chromatographic methods have been developed for the separation of fatty acids in reversed-phase mode, due to the low polarity of their molecules. The most used stationary phase has been $\mathrm{C} 18$, in different isocratic or gradient elution types of mobile phases, the gradient elution being preferred (Table II). In recent years, we have noted a preference towards the use of a mass spectrometer as a detector, this being a powerful tool in precisely identifying the analytes, offering excellent detection limits, good selectivity and, in the same time, being able to be applied to a broad range of compounds.

FA were separated from saliva, serum samples or different types of oil by using a HPLC system with a fluorescence detector $(490 / 510 \mathrm{~nm})$ and a reversed-phase $\mathrm{C} 18$ column with a gradient elution. The most frequent eluents were methanol and double-distilled water (27), or methanol and citrate buffer (23). The methanol content has to be lower than $65 \%$ and the $\mathrm{pH}$ between 6-7.5, otherwise the peaks of the acid derivatives and the reagent become overlapped (27).

The same detector was used for the identification and separation of FAME after the derivatization process. This methyl derivate can be separated by a reversed-phase high performance liquid-chromatography (RP-HPLC) by using a C18 column and a gradient elution. Peaks were identified by UV detection at $205 \mathrm{~nm}$ (28).

FA from blood samples can also be separated and quantified by using an optimized multiple reaction monitoring (MRM) method with the usage of UPLC coupled with tandem mass spectrometry. Chromatography separation was carried out by using a non-polar column and a gradient elution. Gradient program was solvent B (acetonitrile), 70\% (0 min), 90\% (3 min), 100\% (3.01-4 $\mathrm{min}$ ) and 70\% (4.01-8 min). The mobile phase was carried out by using acetonitrile and ammonium acetate $(26,29)$. 
Table II. Separation conditions of FA in LC

\begin{tabular}{|c|c|c|c|c|c|c|}
\hline Sample type & Pre-treatment & $\begin{array}{l}\text { Stationary } \\
\text { phase }\end{array}$ & Mobile phase & $\begin{array}{l}\text { Elution } \\
\text { type }\end{array}$ & Detector & Ref. \\
\hline serum & $\begin{array}{l}\text { isopropanol } \\
\text { extraction }\end{array}$ & $\mathrm{C} 18$ & $\begin{array}{c}\text { A: isopropanol: } \\
\text { ACN:n-hexane }(55: 45: 15) \\
\text { B: } 0.1 \mathrm{~mol} / \mathrm{L} \text { ammonium formiate } \\
\text { methanolic solution }\end{array}$ & $\begin{array}{c}\text { isocratic } \\
\mathrm{A}: \mathrm{B}(95: 5)\end{array}$ & $\mathrm{MS} / \mathrm{MS}$ & (35) \\
\hline $\begin{array}{l}\text { human serum } \\
\text { (healthy, pan- } \\
\text { creatic cancer) } \\
\text { mice liver } \\
\text { tissue }\end{array}$ & $\begin{array}{l}\text { highly } \\
\text { fluorescent } \\
\text { labeling reagent } \\
\text { (derivatization) }\end{array}$ & $\mathrm{C} 18$ & $\begin{array}{c}\text { A: } 15 \mathrm{mM} \text { citrate buffer } \\
\text { B: } \mathrm{MeOH}\end{array}$ & gradient & $\begin{array}{l}\text { fluorescence } \\
\text { detector } \\
(490 / 510 \\
\mathrm{nm})\end{array}$ & (23) \\
\hline $\begin{array}{l}\text { plasma } \\
\text { (human, } \\
\text { hamster) } \\
\text { tissue } \\
\text { (hamster) }\end{array}$ & SPE, LPE & $\mathrm{C} 18$ & $\begin{array}{l}\text { A: } 0.1 \% \text { formic acid in } \mathrm{H}_{2} \mathrm{O} \\
\text { B: } 0.1 \% \text { formic acid in } \mathrm{ACN}\end{array}$ & gradient & $\mathrm{MS} / \mathrm{MS}$ & (24) \\
\hline meibum & $\begin{array}{l}\mathrm{CHCl}_{3} / \mathrm{MeOH} \\
\text { extraction }\end{array}$ & $\mathrm{C} 18$ & $\begin{array}{c}\text { A: } 0.1 \% \text { ammonium acetate in } \mathrm{H}_{2} \mathrm{O} \\
\text { B: } 0.1 \% \text { ammonium acetate in } \\
\text { MeOH }\end{array}$ & gradient & Orbitrap & $(25)$ \\
\hline blood & hexane extraction & $\mathrm{C} 18$ & $\begin{array}{c}\text { A: ammonium acetate } 10 \mathrm{mM} \text { in } \mathrm{H}_{2} \mathrm{O} \\
\text { B: ACN }\end{array}$ & gradient & ESI-MS & (26) \\
\hline $\begin{array}{l}\text { saliva } \\
\text { (smoker, } \\
\text { non-smoker) }\end{array}$ & $\begin{array}{l}\text { fluorescent } \\
\text { derivatization } \\
\text { reagent }\end{array}$ & $\mathrm{C} 18$ & $\begin{array}{l}\text { A: } \mathrm{MeOH} \\
\text { B: } \mathrm{H}_{2} \mathrm{O}\end{array}$ & gradient & $\begin{array}{l}\text { fluorescence } \\
\text { detector } \\
(490 / 510 \\
\mathrm{nm})\end{array}$ & $(27)$ \\
\hline human hair & $\begin{array}{c}\text { DMOX } \\
\text { derivatization }\end{array}$ & $\mathrm{C} 18$ & $\begin{array}{c}\mathrm{A}: \mathrm{MeOH}: \mathrm{H} 2 \mathrm{O}(50: 50)+0.1 \% \text { for- } \\
\text { mic acid } \\
\text { B: } \mathrm{MeOH}+0.1 \% \text { formic acid }\end{array}$ & gradient & $\begin{array}{l}\text { fluorescence } \\
\text { detector } \\
(350 / 450 \\
\mathrm{nm})\end{array}$ & (17) \\
\hline $\begin{array}{l}\text { cell cultures } \\
\text { (cystic fibrosis) }\end{array}$ & $\begin{array}{l}\text { FAME } \\
\text { derivatization }\end{array}$ & $\mathrm{C} 18$ & $\begin{array}{c}\mathrm{A}: \mathrm{H}_{2} \mathrm{O}+0.02 \% \text { fosforic acid } \\
\mathrm{B}: \mathrm{ACN}\end{array}$ & gradient & $\begin{array}{l}\text { UV (205 } \\
\mathrm{nm})\end{array}$ & (28) \\
\hline $\begin{array}{l}\text { plasma (sickle } \\
\text { cell disease) }\end{array}$ & hexane extraction & $\mathrm{C} 18$ & $\begin{array}{c}\text { A: ammonium acetate } 10 \mathrm{mM} \text { in } \mathrm{H}_{2} \mathrm{O} \\
\mathrm{B}: \mathrm{ACN}\end{array}$ & gradient & ESI-MS & (29) \\
\hline plasma (rat) & SPE & $\mathrm{C} 18$ & $\begin{array}{c}\text { A: } \mathrm{H}_{2} \mathrm{O}+0.02 \% \text { formic acid } \\
\text { B: } \mathrm{MeOH}+0.02 \% \text { formic acid }\end{array}$ & gradient & $\begin{array}{l}\text { QqQ-MS } \\
\text { LIT-MS }\end{array}$ & $(30)$ \\
\hline plasma & LPE & $\mathrm{C} 18$ & $\begin{array}{l}\text { A: } \mathrm{H} 2 \mathrm{O}+0.1 \% \text { trifluoracetic acid } \\
\mathrm{B}: \mathrm{ACN}+0.1 \% \text { trifluoracetic acid }\end{array}$ & gradient & MS & $(31)$ \\
\hline plasma & SPE & $\mathrm{C} 18$ & $\begin{array}{l}\mathrm{A}: \mathrm{ACN} \\
\mathrm{B}: \mathrm{H} 2 \mathrm{O}\end{array}$ & gradient & MS/MS & (36) \\
\hline cell culture & $\begin{array}{l}\mathrm{CHCl}_{3} / \mathrm{MeOH} \\
\text { extraction }\end{array}$ & $\mathrm{C} 18$ & $\begin{array}{c}\text { A: } \mathrm{ACN}: \mathrm{MeOH}: \mathrm{H}_{2} \mathrm{O}(19: 19: 2)+ \\
0.1 \% \text { acetic acid }+0.028 \% \mathrm{NH}_{3} \\
\text { B: isopropanol }+0.1 \% \text { acetic } \\
\text { acid }+0.028 \% \mathrm{NH}_{3}\end{array}$ & gradient & ESI-MS & (4) \\
\hline
\end{tabular}


Reversed phase liquid chromatography can be coupled along with direct electron impact mass spectrometry (EI-MS). This method has the advantage of not requiring derivatization of the sample and not showing matrix effect (31). According to this, the time of analysis can be reduced, however, when dealing with a complex matrix, such as plasma, the separation is anticipated by a liquid-liquid extraction, which can take about 30 minutes. This method can be used for the detection of all NEFAs in plasma with a satisfactory sensitivity and selectivity, because the direct EI-MS response is not affected by co-eluting endogenous plasma components (31).

The analyses of plasma samples collected from genetically obese, spontaneously hypertensive female rats were carried out on two LC-MS systems; one was coupled to a triple quadrupole MS, and the other was coupled to a LIT mass spectrometer. The operating conditions of the ESI source in both cases were negative ion mode, and acceptable precision was achieved by both instruments. The LIT system had the advantages of lower matrix effect and higher global recovery than in the case of the QqQ system. Although the QqQ assays were highly sensitive, when applied to rat plasma samples, they gave several false identifications, because many isomers with similar MRM transitions were co-eluted (30).

By using an Orbitrap Fourier transform mass spectrometer as detector, FAs and OAHFAs were separated by using a negative ion mode because OAHFAs, like FAs, possess a carboxylic group. As well as in the case of the QqQ system, this method also identified a number of molecular species in one chromatographic peak, demonstrating co-elution of isomers of OAHFA molecular species. The main advantage of this method is that long chain fatty acids could be separated without a derivatization process. Mori and co-workers succeeded identifying $61 \mathrm{OAH}-$ FA molecular species with 34-56 carbon atoms by using this method. The species with the high- est abundance were C18:1/32:1, C18:1/30:1, C16:1/32:1 (25).

Human skin fibroblasts from X-ALD or Zellweger patients were analyzed by using the same LC-ESI-MS/MS method. For acidic phospholipids MS/MS analysis was performed in negative ion mode, while phospholipids with choline were detected in positive ion mode. The lipids were eluted from the reversed-phase column in accordance with their hydrophobicity and exhibited molecular ion signals dependent on their mass/charge $(\mathrm{m} / \mathrm{z})$. The longest fatty acyl chains detected were $\mathrm{C} 36$, and the highest unsaturated bond number observed was 6 .

Separation of fatty acid ethanolamides by UPLC-MS/MS was performed on a C18 column by using a gradient condition: over the first 2 min mobile phase B (acetonitrile with $0.1 \%$ formic acid) was increased from $70 \%$ to $72 \%$ and in the subsequent 6 min increased to $74 \%$. The tandem MS equipped with an atmospheric pressure ionization (API) probe was operated in positive electrospray ionization mode (+ESI), because of the structure of the ethanolamides (24).

\section{Alternative analitical techniques}

Capillary electrophoresis (CE) represents an alternative to chromatographic methods which gives high efficiency, low separation times and high reproducibility. However, there are few studies which deal with electrophoretic separation of fatty acids (32) compared to GC-MS studies or HPLC-MS studies and even fewer dealing with biological samples. Similar to HPLC, capillary electrophoresis presents the disadvantage of the UV detection, because fatty acids hardly absorb in this spectral range. However, in addition to the MS detector which can be coupled to the CE system, other types of detectors can be used, such as the contactless conductivity detectors (37).

Alternatively to the separation methods, spectral techniques such as ATR-FT-IR and Ra- 
man spectroscopy $(33,38)$ can be used for the analysis of fatty acids. These methods, coupled with the multivariate analysis of spectral data can give rapid quantitative information about the analyzed sample (38). These complementary spectroscopic methods provide very fast analysis times (seconds to few minutes), specificity towards the analyte through the fingerprint spectral area and very low consumption of solvents.

\section{Potential clinical utility of fatty acids profile analysis}

There are two main directions is which the fatty acids composition in biological samples have been studied: the presence of a malignant state and the presence of a disorder related to the metabolic syndrome. In the first case, authors $(12,13,15)$ have separated FA from colorectal cancer tissue and healthy adjacent cells as control obtained postoperatively, and from erythrocyte membranes in multiple myeloma patients, after derivatization to FAME. Results showed, in all cases, an increase in the profile of some saturated fatty acids (SFA) and also a decrease in the profile of mono-unsaturated fatty acids (MUFA) in the cancerous tissue compared to the normal cells. In the same time, a decrease in the n-3/n-6PUFA ratio has been observed in the malignant tissue, compared to the normal cells. Moreover, Mal and co-workers (12) have realized an entire biochemical metabotyping of colorectal cancer, using GCxGC-TOF-MS, where they have remarked not only different profiles of FA, but also of amino-acids and saccharides, with important roles in biochemical cell stages.

The most important disorder related to the metabolic syndrome is diabetes mellitus, usually because of its complications. Authors have studied FA in plasma from patients with this disease $(1,5,6)$, but also FA from insulin secreting cells INS-1 have been separated using GCxGC-TOFMS (11) and plasma from other disorders related to insulin resistance, such as polycystic ovary syndrome (PCOS) (14). In the last case, results have showed that insulin resistance has a bigger influence on the fatty acids profile than the presence of PCOS. Nervonic acid (C24:1 n-9) was identified as a biomarker for the presence of PCOS and dihomo- $\gamma$-linolenic acid (DGLA) was identified as a biomarker for insulin resistance, after multivariate interpretation of data. Moreover, authors have noticed, as in case of malignant diseases, a decreased ratio of n-3/n-6 PUFA in case of PCOS with insulin resistance, compared to control or with non-insulin resistant PCOS, but also a modified profile of MUFA in PCOS. In the same time, Han et al. (5) have identified the arachidonic acids (C20) to be biomarkers in the plasma of diabetic patients, with or without different stages of nephropathy, as a diabetic complication. Moreover, they have noticed, compared to control, an increase in the EFA profiles and a decrease in the NEFA profiles in the plasma of diabetic patients. This can be related to insulin resistance and/or lack of insulin. At the same time, Sertoglu and co-workers (6) have noticed that the $n-3 / n-6$ ratio is the lowest in plasma of diabetic patients compared to control or to end-stage renal disease patients, but the $n-3 / n-6$ ratio is the highest when determined from the erythrocyte membranes of the same groups. When analyzing plasma samples from obese patients by GC-FID, Tremblay-Franco et al. (39) discovered that the n-9 FA ratio decreased and n-7 ratio increased in case of obese females, compared to control.

All these findings can be explained in all cases due to the anti-inflammatory, cardioprotective, neuroprotective effects of n-3 PUFA and the opposite effects of n-6 PUFA, thus the pathological effects are reflected in the $n-3 / n-6$ PUFA ratio. Arakawa et al. (40) have pointed out the importance of n-3 PUFA intake, their cardioprotective properties and have showed that the total serum levels of DHA and EPA can be pre- 
dictor of ischemia immediately after myocardial reperfusion, thus can predict a myocardial damage. Moreover, Nishi et al. (1) have shown that a daily ingestion of n-3 PUFA through different types of supplements (e.g. nuts) can improve the FA profile in diabetic patients, with decreasing their coronary heart disease risk. For the same reason, authors (16) have studied recovery from patients with periodontitis, after administering supplements with n-3-PUFA, considering the anti-inflammatory effects of this type of FA. Results have shown a better recovery at patients having n-3-PUFA supplements than controls. In the same time, n-3 PUFA have proved their cardioprotective properties and the total serum levels of EPA and DHA can be used as predictors for the level of ischemia after myocardia reperfusion (40).

The fatty acids profile seems to be modified even in infectious diseases. Khedr et al. (34) have identified several EFA as biomarkers for the early febrile stage of the dengue fever disease; among them: the esterified C14:0, C16:0, C18:0, C20:4-n6, C22:6-n3, which, in all cases, had a decreased profile in the blood of infected patients compared to control.

It has been demonstrated that the same saturated fatty acids, C16:0 and C18:0 are present in lower amounts in the meibum of meibomian gland dysfunction patients than control. Meibum lipids are a highly complex mixture of lipids from various classes, including OAHFAs. These species decrease as the severity of dry eye disease increase, so they can be considered as a potential biomarker in meibomian gland dysfunction. It is important to elucidate the relationship between odd number FA and bacterial infections in meibomian gland dysfunction patients, because bacteria can produce an odd number of FAs (25). On the other hand many hydroxyl-derived compounds of EPA and DHA are involved in the regulation of vascular tone, arteriosclerosis and are considered markers of lipid peroxidation (30).
The level of propionic acid in the smokers' saliva is higher than in the nonsmokers', and the level of heptanoic acid in the smokers' saliva is lower than in the case of nonsmokers (27). The level of C16:0, C18:1, and C18:0 in the serum of patients dealing with advanced pancreatic cancer is higher than the dosage found in the serum of healthy patients (23).

It has been demonstrated that by increasing the concentration of substrates from the parallel n- 3 and n- 6 polyunsaturated fatty acid pathways, the formation of the products in that pathways also increases and metabolism in the parallel pathway is reduced. DHA and EPA suppress the expression of both $\Delta 5$ and $\Delta 6$-desaturases and normalize LNA and AA levels (28). Because of the pro-inflammatory and immunoactive functions of the AA, the increase of this fatty acid in serum and AA/EPA ratio can be considered a biomarker in many diseases which include a pro-inflammatory state like sickle cell disease, obesity or cystic fibrosis.

Elevated plasma AA levels may thus be a source of pro-aggregatory substances in case of sickle cell disease patients (29). On the other hand, AA deficiency may predispose human organism to developing type 2 diabetes mellitus, because a significant decrease of the principal n-6 PUFA and AA has been observed in diabetic patients (26). Moreover, NEFA's concentrations were found to be higher in plasma samples of diabetic patients (31).

Cystic fibrosis is the most common lethal genetic disease in Caucasian population, which presents an alteration of plasma levels of polyunsaturated fatty acids. The major ones are decreases in linoleate and docosahexaenoate and increases in palmitoleate and mead acid. In case of cystic fibrosis the AA increases only at the highest LNA:ALA ratio, and the production of AA is influenced by ALA, the initial substrate of the parallel n-3 pathways. Also EPA levels were higher and DHA levels lower in cystic fibro- 
sis compared to healthy patients. Katrangi and co-workers also demonstrated that the serum ratio of LNA to ALA has a greater impact on LNA to AA metabolism than on ALA to EPA metabolism. The increased production of AA plays a significant role on cystic fibrosis related inflammation (28).

Levels of FAE have been shown to vary between species, in hamster plasma samples the mean levels of OEA and PEA are higher compared to human plasma samples. Compared to plasma samples, levels of AEA were higher in the intestine and in hamster liver. The concentration gradient for hamster liver and small intestine was shown to be PEA $>\mathrm{OEA}>\mathrm{AEA}$, but further investigation is required in order to fully understand FAE distribution patterns in case of different tissues. Levels of OEA can be influenced by the volunteers' physiological state and also by the type of dietary treatments (24).

Very long chain fatty acids (VLCFA) are minor constituents and are difficult to detect and separate. They are biosynthesized from fatty acids by elongase and they are degraded by $\beta$-oxidation in peroxisomes. In genetic peroxisomal diseases, such as Zellweger syndrome and X-linked adrenoleukodystrophy (X-ALD), VLCFA are known to accumulate and increase intracellular calcium concentrations and decrease mitochondrial respiration, which can lead to cell death in oligodendrocytes and astrocytes. The accumulation of VLCFA, including C26:0 has been accepted as the principal biochemical abnormality in X-ALD and Zellweger syndrome. The proportions of sphingomyelin with C26:0, C26:1 and C26:2 were significantly increased in peroxisomal disease (4). New molecular species with VLCFA were found in the phospholipids classes of phosphatidyl-ethanolamine and phosphatidyl-serine, which can be used as new biomarkers for peroxisomal diseases. The main disadvantage was the observed differences in the molecular species between patients (4).
Milk is the primary food and also comes as a biological fluid $(7,8)$. Authors have revealed by GC-FID analysis that the FA profile in human milk is different from that in infant formulas (7), where essential fatty acids and their eicosanoids had less concentrations in the commercial formulations than in human milk. However, Cruz-Hernandez and co-workers (8) showed an inter-individual variability in fatty acids profile in human milk, which is to be taken in consideration. But a supplementation with DHA at lactating mothers can increase this fatty acid's profile in milk and plasma and also, can improve the n-3/n-6 PUFA ratio in these biological fluids (41).

All of the up-mentioned clinical implications of fatty acids profiles are listed in Table III.

\section{Conclusions}

This paper has presented an extensive literature review of the recent years, regarding the most important techniques for the analysis of fatty acids in biological samples. We have presented the main utilized methods in each case, but also have noted unusual methods which can be successfully used. GC-MS is the main chromatographic technique applied in clinical lab for the analysis of fatty acids from serum, plasma and other biological fluids or tissues, after their methyl-transesterification. In the same time, HPLC or CE coupled with different types of detectors can be successfully used for the analysis of fatty acids in these bio-samples. Alternative spectral methods, like infrared and Raman spectroscopy, have been used for the analysis of fatty acids, mostly coupled with multivariate analysis of data.

We have also presented the most important results obtained along with the clinical relevance of fatty acids profiles and, as applicable, biomarkers or fatty acids with importance in the presence or diagnosis of the investigated diseases. The n-3/n-6 PUFA ratio can be pointed out 
as an important factor in many diseases, starting from inflammatory states and diabetes mellitus up to cancerous states.

\section{Aknowledgement}

This paper was published under the frame of European Social Found, Human Resources Development Operational Programme 20072013, project no. POSDRU/159/1.5/S/136893.

\section{Abbreviations}

AA (arachidonic acid);

AEA (arachidonyl-ethanolamide);

ALA (alpha-linolenic acid);

ALEA (alpha-linolenoyl-ethanolamide);

ATR-FT-IR (attenuated total reflectance Fourier transform infrared spectroscopy);

CE (capillary electrophoresis);

DCM (dichloromethane);

Table III. Potential clinical utility of FA profiles in different diseases

\begin{tabular}{|c|c|c|c|c|c|}
\hline Diseases & $\begin{array}{l}\text { Analyzed } \\
\text { sample }\end{array}$ & Method & Biomarkers & FA profile & Ref. \\
\hline colorectal cancer & colon tissue & GCXGC/ TOFMS & N/A & $\begin{array}{c}\text { decrease ratio of n-3/n-6 PUFA ratio } \\
\text { increase SFA }\end{array}$ & $(12,13)$ \\
\hline pancreatic cancer & human serum & $\begin{array}{l}\text { HPLC-fluores- } \\
\text { cence detector }\end{array}$ & N/A & $\begin{array}{c}\text { increase in C16:0, C18:1, and C18:0 } \\
\text { serum levels }\end{array}$ & $(23)$ \\
\hline $\begin{array}{l}\text { neurologic/ psy- } \\
\text { chiatric }\end{array}$ & brain samples & TLC, GC-FID & $\begin{array}{l}\text { cholesteryl } \\
\text { esters }\end{array}$ & $\begin{array}{c}\text { decrease of AA and DHA concen- } \\
\text { tration }\end{array}$ & (2) \\
\hline $\begin{array}{l}\text { X-ALD, } \\
\text { Zellweger }\end{array}$ & cell culture & LC-ESI-MS/MS & $\begin{array}{l}\mathrm{C} 26: 0 / \mathrm{C} 22: 0 \\
\text { ratio }\end{array}$ & increase of VLCFA levels & (4) \\
\hline $\begin{array}{l}\text { sickle cell } \\
\text { disease }\end{array}$ & human plasma & UFLC & $\begin{array}{l}\mathrm{AA} / \mathrm{EPA} \\
\text { ratio }\end{array}$ & $\begin{array}{l}\text { increase in AA and DGLA levels } \\
\text { decrease of EPA and DHA levels }\end{array}$ & $(29)$ \\
\hline cystic fibrosis & $\begin{array}{l}\text { human bron- } \\
\text { chial epitheli- } \\
\text { al cells }\end{array}$ & RP-HPLC & $\begin{array}{l}\text { LNA:ALA } \\
\text { ratio }\end{array}$ & $\begin{array}{c}\text { increases in EPA, C16:1 and mead } \\
\text { acid levels } \\
\text { decrease in C18:2, DHA levels }\end{array}$ & $(28)$ \\
\hline $\begin{array}{l}\text { meibomian gland } \\
\text { dysfunction }\end{array}$ & $\begin{array}{l}\text { human } \\
\text { meibum }\end{array}$ & LC-FTMS & N/A & $\begin{array}{c}\mathrm{C} 16: 0 \text { and } \mathrm{C} 18: 0 \text { are present in low- } \\
\text { er amounts }\end{array}$ & $(25)$ \\
\hline $\begin{array}{l}\text { polycystic ovary } \\
\text { syndrome }\end{array}$ & plasma & (GC-MS) & $\begin{array}{l}\text { nervonic acid } \\
(\mathrm{C} 24: 1 \mathrm{n}-9) \\
\quad-\mathrm{PCOS} \\
\end{array}$ & decreased ratio of n-3/n-6 PUFA & (14) \\
\hline insulin resistance & plasma & GC-MS & $\begin{array}{l}\text { diho- } \\
\text { mo- } \gamma \text {-lino- } \\
\text { lenic acid } \\
\text { (DGLA) }\end{array}$ & decreased ratio of n-3/n-6 PUFA & (14) \\
\hline diabetes mellitus & $\begin{array}{l}\text { human } \\
\text { plasma }\end{array}$ & $\begin{array}{c}\text { UFLC-MS/MS } \\
\text { LC-EI-MS } \\
\text { GC-MS } \\
\text { GC-FID }\end{array}$ & $\begin{array}{l}\text { arachidonic } \\
\text { acids (C20) }\end{array}$ & $\begin{array}{l}\text { increase in the EFA } \\
\text { decrease in the NEFA and AA }\end{array}$ & $(5,6,11,31)$ \\
\hline $\begin{array}{l}\text { myocardial in- } \\
\text { farction }\end{array}$ & serum & GC & $\begin{array}{l}\text { total } \\
\mathrm{DHA}+\mathrm{EPA} \\
\text { profile }\end{array}$ & $\begin{array}{l}\text { DHA+EPA profile significantly cor- } \\
\text { related with the size of ischemia }\end{array}$ & $(40)$ \\
\hline
\end{tabular}


DHA (docohexaenoic acid);

DHEA (docohexaenoyl-ethanolamide);

DMOX (4,4-dimethyl-oxazoline);

EFA (esterified fatty acid);

EPA (eicosapentaenoic acid);

FA (fatty acid);

FAE (fatty acid ethanolamide);

FAME (fatty acid methyl ester);

GC-FID (gas chromatography coupled with

flame ionization detector);

GC-MS (gas chromatography coupled with mass spectrometer detector);

HPLC-MS (high performance liquid chromatography coupled with mass spectrometer detector); LC-ESI-MS (liquid chromatography coupled with electro-spray ionization mass spectrometer detector);

LEA (linoleoyl-ethanolamide);

LNA (linoleic acid);

LPE (liquid phase extraction);

MSTFA (N-methyl-N-trifluoroacetamide);

MUFA (mono-unsaturated fatty acid);

NEFA (non-esterified fatty acid);

OAHFA (O-acyl-hydroxy-fatty acid);

OEA (oleyl-ethanolamide);

PEA (palmitoyl-ethanolamide);

PUFA (poly-unsaturated fatty acid);

SPE (solid phase extraction);

TOF-MS (time of flight mass spectrometry);

UPLC-MS (ultra-high performance liquid chromatography coupled with mass spectrometer detector);

VLCFA (very long chain fatty acid).

\section{References}

1. Nishi SK, Kendall CWC, Bazinet RP, Bashyam B, Ireland C, Augustin LS, et al. Nut consumption, serum fatty acid profile and estimated coronary heart disease risk in type 2 diabetes. Nutr Metab Cardiovasc Dis. 2014 Aug;24(8):845-52. DOI: 10.1016/j.numecd.2014.04.001

2. Taha AY, Cheon Y, Ma K, Rapoport SI, Rao JS. Altered fatty acid concentrations in prefrontal cortex of schizophrenic patients. J Psychiatr Res 2013 May;47(5):63643. DOI: $10.1016 /$ j.jpsychires.2013.01.016
3. Johnson M, Månsson JE, Ostlund S, Fransson G, Areskoug B, Hjalmarsson K, et al. Fatty acids in ADHD: plasma profiles in a placebo-controlled study of Omega $3 / 6$ fatty acids in children and adolescents. Atten Defic Hyperact Disord. 2012 Dec;4(4):199-204. DOI: 10.1007/s12402-012-0084-4

4. Hama K, Nagai T, Nishizawa C, Ikeda K, Morita M, Satoh N, et al. Molecular species of phospholipids with very long chain fatty acids in skin fibroblasts of Zellweger syndrome. Lipids 2013. Dec;48(12):1253-67.

5. Han LD, Xia JF, Liang QL, Wang Y, Wang YM, Hu P, et al. Plasma esterified and non-esterified fatty acids metabolic profiling using gas chromatography-mass spectrometry and its application in the study of diabetic mellitus and diabetic nephropathy. Anal Chim Acta. 2011 Mar;689(1):85-91. DOI: 10.1016/j.aca.2011.01.034

6. Sertoglu E, Kurt I, Tapan S, Uyanik M, Serdar M, Kayadibi $\mathrm{H}$, et al. Comparison of plasma and erythrocyte membrane fatty acid compositions in patients with end-stage renal disease and type 2 diabetes mellitus. Chem Phys Lipids. 2014 Mar;178:11-7. DOI: 10.1016/j.chemphyslip.2013.12.011

7. Chuang CK, Yeung CY, Jim WT, Lin SP, Wang TJ, Huang SF, et al. Comparison of free fatty acid content of human milk from Taiwanese mothers and infant formula. Taiwan J Obstet Gynecol. 2013 Dec;52(4):52733. DOI: $10.1016 /$ j.tjog.2013.10.013

8. Cruz-Hernandez C, Goeuriot S, Giuffrida F, Thakkar SK, Destaillats F. Direct quantification of fatty acids in human milk by gas chromatography. J Chromatogr A. 2013 Apr;1284:174-9. DOI: 10.1016/j.chroma.2013.01.094

9. Kremmyda LS, Vlachava M, Noakes PS, Diaper ND, Miles E, Calder PC. Atopy risk in infants and children in relation to early exposure to fish, oily fish, or longchain omega-3 fatty acids: a systematic review. Clin Rev Allergy Immunol. 2011 Aug;41(1):36-66. DOI: 10.1007/s 12016-009-8186-2

10. Fontes JD, Rahman F, Lacey S, Larson MG, Vasan RS, Benjamin EJ, et al. Red blood cell fatty acids and biomarkers of inflammation: A cross-sectional study in a community-based cohort. Atherosclerosis. 2015 Jun;240(2):431-6. DOI: 10.1016/j.atherosclerosis.2015.03.043

11. Payeur AL, Lorenz M, Kennedy RT. Analysis of fatty acid composition in insulin secreting cells by comprehensive two-dimensional gas chromatography time-offlight mass spectrometry. J Chromatogr B Anal Technol Biomed Life Sci. 2012 Apr;893-894:187-92. DOI: 10.1016/j.jchromb.2012.03.003

12. Mal M, Koh PK, Cheah PY, Chan ECY. Metabotyping of human colorectal cancer using two-dimensional gas chromatography mass spectrometry. Anal Bioanal Chem 2012 Apr;403(2):483-93. DOI: 10.1007/s00216012-5870-5 
13. Zhang J, Zhang L, Ye X, Chen L, Zhang L, Gao Y, et al. Characteristics of fatty acid distribution is associated with colorectal cancer prognosis. Prostaglandins Leukot Essent Fat Acids. 2013 May;88(5):355-60. DOI: 10.1016/j.plefa.2013.02.005

14. Zhang XJ, Huang LL, Su H, Chen YX, Huang J, He $\mathrm{C}$, et al. Characterizing plasma phospholipid fatty acid profiles of polycystic ovary syndrome patients with and without insulin resistance using GC-MS and chemometrics approach. J Pharm Biomed Anal. 2014 Jul;95:8592. DOI: 10.1016/j.jpba.2014.02.014

15. Jurczyszyn A, Czepiel J, Gdula-Argasińska J, Czapkiewicz A, Biesiada G, Dróżdż M, et al. Erythrocyte membrane fatty acids in multiple myeloma patients. Leuk Res. 2014 Oct;38(10):1260-5. DOI: 10.1016/j. leukres.2014.08.009

16. Wang SH, Hung HC, Tsai CC, Huang MC, Ho KY, $\mathrm{Wu} \mathrm{YM}$, et al. Plasma polyunsaturated fatty acids and periodontal recovery in Taiwanese with periodontitis: A significant relationship. Arch Oral Biol. 2014 Aug;59(8):800-7. DOI: 10.1016/j.archoralbio.2014.04.009

17. Takahashi T, Yoshida S. Distribution of Glycolipid and Unsaturated Fatty Acids in Human Hair. Lipids. 2014 Sep;49(9):905-17. DOI: 10.1007/s11745-014-3937-0

18. Enke U, Jaudszus A, Schleussner E, Seyfarth L, Jahreis G, Kuhnt K. Fatty acid distribution of cord and maternal blood in human pregnancy: special focus on individual trans fatty acids and conjugated linoleic acids. Lipids Health Dis. 2011 Dec;10(1):247. DOI: 10.1186/1476$511 \mathrm{X}-10-247$

19. Wang DC, Sun CH, Liu LY, Sun XH, Jin XW, Song WL, et al. Serum fatty acid profiles using GC-MS and multivariate statistical analysis: potential biomarkers of Alzheimer's disease. Neurobiol Aging. 2012 Jun;33(6):1057-66. DOI: 10.1016/j.neurobiolaging.2010.09.013

20. Castro-Gómez P, Fontecha J, Rodríguez-Alcalá LM. A high-performance direct transmethylation method for total fatty acids assessment in biological and foodstuff samples. Talanta. 2014 Oct;128:518-23. DOI: 10.1016/j.talanta.2014.05.051

21. Ecker J, Scherer M, Schmitz G, Liebisch G. A rapid GCMS method for quantification of positional and geometric isomers of fatty acid methyl esters. J Chromatogr B. Anal Technol Biomed Life Sci. 2012 May;897:98-104. DOI: $10.1016 /$ j.jchromb.2012.04.015

22. Kopf T, Schmitz G. Analysis of non-esterified fatty acids in human samples by solid-phase-extraction and gas chromatography/mass spectrometry. J Chromatogr B. 2013 Nov;938:22-6. DOI: 10.1016/j. jchromb.2013.08.016

23. Wang F, Xiong X, Guo X, Wang H, Zhang H. Determination of fatty acids in bio-samples based on the pre-column fluorescence derivatization with 1,3,5,7-te- tramethyl-8-butyrethylenediamine-difluoroboradiaza-s-indacene by high performance liquid chromatography. J Chromatogr A. 2013 May;1291:84-91. DOI: 10.1016/j.chroma.2013.03.062 DOI: 10.1016/j.chroma.2012.12.045

24. Lin L, Yang H, Jones PJH. Quantitative analysis of multiple fatty acid ethanolamides using ultra-performance liquid chromatography-tandem mass spectrometry. Prostaglandins Leukot Essent Fat Acids. 2012 Dec;87(6):189-95. DOI: 10.1016/j.plefa.2012.09.001

25. Mori N, Fukano Y, Arita R, Shirakawa R, Kawazu K, Nakamura M, et al. Rapid identification of fatty acids and (O-acyl)- $\omega$-hydroxy fatty acids in human meibum by liquid chromatography/high-resolution mass spectrometry. J Chromatogr A. 2014 Jun;1347:129-36. DOI: 10.1016/j.chroma.2014.04.082

26. Aslan M, Aslan I, Özcan F, Eryılmaz R, Ensari CO, Bilecik T. A pilot study investigating early postoperative changes of plasma polyunsaturated fatty acids after laparoscopic sleeve gastrectomy. Lipids Health Dis. 2014 Jan;13:62. DOI: 10.1186/1476-511X-13-62

27. Guo XF, Li Y, Wang H, Zhang HS. Determination of Fatty Acids in Saliva of Smokers and Nonsmokers by HPLC with Fluorescence Detection Using a Hydrazine-Based Difluoro-boraindacene Reagent. Chromatographia. 2014 Feb;77(5-6):431-8. DOI: 10.1007/ s10337-014-2627-7

28. Katrangi W, Lawrenz J, Seegmiller AC, Laposata M. Interactions of linoleic and alpha-linolenic acids in the development of fatty acid alterations in cystic fibrosis. Lipids. 2013 Apr;48(4):333-42. DOI: 10.1007/s11745013-3768-4

29. Aslan M, Celmeli G, Ozcan F, Kupesiz A. LC-MS/ MS analysis of plasma polyunsaturated fatty acids in patients with homozygous sickle cell disease. Clin Exp Med. 2014 Aug; 15(3):397-403 DOI: 10.1007/s10238014-0293-6

30. Dasilva G, Pazos M, Gallardo JM, Rodríguez I, Cela R, Medina I. Lipidomic analysis of polyunsaturated fatty acids and their oxygenated metabolites in plasma by solid-phase extraction followed by LC-MS. Anal Bioanal Chem. 2014 May;406(12):2827-39. DOI: 10.1007/s00216-014-7701-3

31. Trufelli H, Famiglini G, Termopoli V, Cappiello A. Profiling of non-esterified fatty acids in human plasma using liquid chromatography-electron ionization mass spectrometry. Anal Bioanal Chem. 2011 Jul;400(9):2933-41. DOI: 10.1007/s00216-011-4955-x

32. Mendonça P, Barra DC, Macêdo M, Stremel M, Fett $\mathrm{R}$, Amadeu $\mathrm{G}$, et al. A rapid method for monitoring total trans fatty acids (TTFA) during industrial manufacturing of Brazilian spreadable processed cheese by capillary zone electrophoresis. Food Control. 2012 Feb;23(2):456-61. DOI: 10.1016/j.foodcont.2011.08.014 
33. Stiebing C, Matthäus C, Krafft C, Keller AA, Weber $\mathrm{K}$, Lorkowski S, et al. Complexity of fatty acid distribution inside human macrophages on single cell level using Raman micro-spectroscopy. Anal Bioanal Chem. 2014 Nov;406(27):7037-46. DOI: 10.1007/s00216014-7927-0

34. Khedr A, Hegazy M, Kamal A, Shehata M. Profiling of esterified fatty acids as biomarkers in the blood of dengue fever patients using a microliter-scale extraction followed by gas chromatography and mass spectrometry. J Sep Sci. 2015 Jan;38(2):316-24. DOI: 10.1002/ jssc. 201400749

35. Yu S, Dong J, Zhou W, Yang R, Li H, Zhao H, et al. A rapid and precise method for quantification of fatty acids in human serum cholesteryl esters by liquid chromatography and tandem mass spectrometry. J Chromatogr B. 2014 Jun;960:222-9. DOI: 10.1016/j. jchromb.2014.04.040

36. Kortz L, Dorow J, Becker S, Thiery J, Ceglarek U. Fast liquid chromatography-quadrupole linear ion trap-mass spectrometry analysis of polyunsaturated fatty acids and eicosanoids in human plasma. J Chromatogr B Anal Technol Biomed Life Sci. 2013 May;927:209-13. DOI: $10.1016 /$ j.jchromb.2013.03.012

37. Wong YF, Saad B, Makahleh A. Capillary electrophoresis with capacitively coupled contactless conductivity detection for the determination of cis/trans isomers of octadec-9-enoic acid and other long chain fatty acids. J Chromatogr A. 2013 May;1290:82-90. DOI: 10.1016/j. chroma.2013.03.014

38. Takahashi T, Yoshida S. Distribution of glycolipid and unsaturated Fatty acids in human hair. Lipids. 2014 Sep;49(9):905-17. DOI: 10.1007/s11745-014-3937-0

39. Tremblay-Franco M, Zerbinati C, Pacelli A, Palmaccio G, Lubrano C, Ducheix S, et al. Effect of obesity and metabolic syndrome on plasma oxysterols and fatty acids in human. Steroids. 2015 May;99:287-92. DOI: 10.1016/j.steroids.2015.03.019

40. Arakawa K, Himeno H, Kirigaya J, Otomo F, Matsushita K, Nakahashi H, et al. Impact of n-3 polyunsaturated fatty acids in predicting ischemia/reperfusion injury and progression of myocardial damage after reperfusion in patients with ST-segment elevation acute myocardial infarction. J Cardiol. 2015 Aug;66(2):101-7. DOI: $10.1016 /$ j.jjcc.2015.03.009

41. Sherry CL, Oliver JS, Marriage BJ. Docosahexaenoic acid supplementation in lactating women increases breast milk and plasma docosahexaenoic acid concentrations and alters infant omega 6:3 fatty acid ratio. Prostaglandins, Leukot Essent Fat Acids. 2015 Apr;95:63-9. DOI: 10.1016/j.plefa.2015.01.005 